\title{
Kyanite and Staurolite Detrital Grains: Chemistry and Occurrence in Recent Sediments of Tigris River, Northern Iraq
}

\author{
Mohsin M. Ghazal \\ Department of Geology \\ College of Science \\ Mosul University
}

\author{
Ali I. Al-Juboury \\ Research Center for Dams and Water \\ Resources \\ Mosul University
}

(Received 31/5/2006, Accepted 20/9/2006)

\begin{abstract}
The present work describes the mineralogy and optical properties of the detrital kyanite and staurolite occurring in the recent deposits of Tigris River and its tributaries in northern Iraq using thin section microscopy and scanning electron microscopy. In addition, chemical analyses are obtained using electron microprobe analyzer for the detrital kyanite and staurolite grains and then were used as indicators to elucidate the provenance; by comparing their chemistry with the same minerals in the metamorphic rocks of Turkey. There is a good similarity in mineral chemistry between them affirming that the detrital kyanite and staurolite are derived from the metamorphic rocks (schist) that contain kyanite and staurolite, which are transported by Tigris River to the Iraqi territories after the process of disintigration.
\end{abstract}

\section{حبيبل الكليلاليت والمتورولايت الغتلنية: الكيميائية والتواجدف الرولسب الحيثة لنهر نجالة فيشمل العرق}

\section{الملغص}

في الدرلسة الحالية وصفت الخواص المعنية والبصرية لمعني الكايانايت وللستورولايت الموجولة

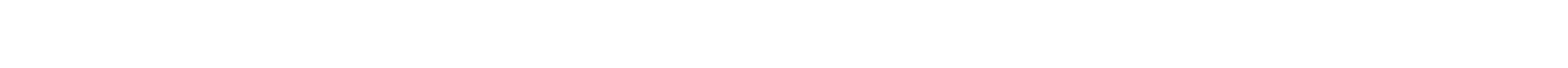

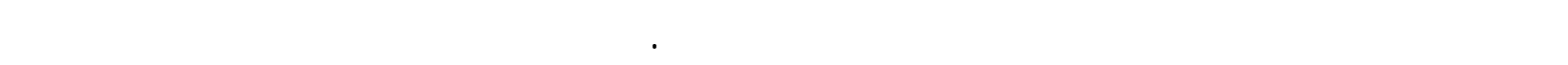
الكيميائي بالمجس الالكتروني لتحديد كيميائية المعان المدروسة، ومن ثم لستخدم التحليل دليلا للهد تتبطا

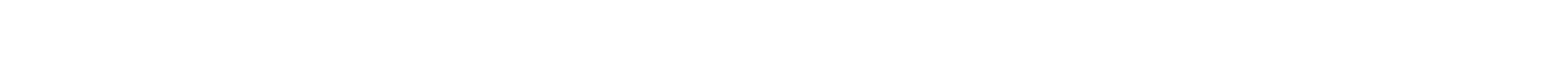

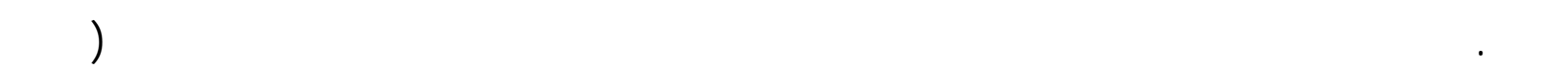

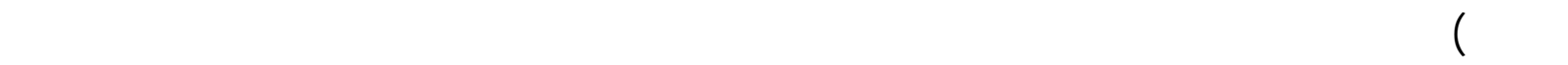




\section{INTRODUCTION}

Heavy mineral assemblages in river sediments closely reflect the nature of the source area, their composition is affected by a variety of other processes operating during the sedimentary cycle, these include; weathering in the source area, the effects of transportation process, the hydraulic conditions at the depositional environment and the diagenetic processes (Morton and Johnsson, 1993).

The chemistry of individual minerals compared to that of the probable source rocks is more advantageous in concerning provenance studies (Morton, 1985; Acquafredda et al., 1997).

Kyanite and staurolite were identified in the heavy fractions of the recent sediments of the Tigris River and its tributaries from northern Iraq (Phillip, 1968; Al-Juboury et al., 2001a), and in some of the older sediments of Eocene Gercus Formation (Al-Rawi, 1980); in Miocene clastics of the upper unit of the Fat'ha Formation (Al-Juboury et al., 2001b); the Injana Formation (Al-Juboury, 1994; Al-Juboury, 2001), as well as in the Quaternary Tigris river terraces of northern Iraq (Al-Juboury, et al., 2001c).

The present work is conducted using the petrographic microscope to determine the mineralogical characteristic of kyanite and staurolite grains. The chemistry of kyanite and stautolite is performed using electron microprobe analyses in order to provide new information on provenance area. Furthermore, scanning electron microscopic investigation of these minerals is performed to observe the environmental changes affecting these minerals. The chemical data are compared with the same mineral chemistry from Turkey.

From the mineralogical, chemical and morphological evidences of the studied kyanite and staurolite, the present study attempts to elucidate the provenance and depositional history of kyanite and staurolite grains.

\section{GENERAL GEOLOGY}

The Tigris River crosses the southern parts of Turkey, which is a very complex igneous and metamorphic region (Nappe Zone), while most of its tributaries have risen from NE Nappe Zone (i.e. across the Mawat-Chuwarta Ophiolite Complex area). The Nappe Zone includes the area of north and northeast Iraq, forming the high and tectonically complex Zagros Mountains which trend northwest-southeast. This area is the headwaters of a number of rivers which drain southwestward to the Tigris River. The main sediments that crop out range in age from Jurassic to Quaternary. This zone has undergone widespread igneous activity including the intrusion of dolerite, gabbro and granite, and the extrusion of andesite and basalt (Jawad Ali, 1977; Buday, 1980) as well as explosive pyroclastics and tuff. Rocks in this zone show a low grade of metamorphism (e.g. slates, phyllites, schists and spilites) (Fig.1).

In Iraq, the Tigris River in its upper reaches receives a number of tributaries, principally the Greater and Lesser Zab Rivers. These drain the highly folded and faulted igneous and metamorphic thrust zone (Dunnington, 1958) in extreme northeastern Iraq, where the Tigris River cuts through the lower competent fold mountains and foot-hills belt zones. It exposes Paleocene- Eocene rocks (Pila Spi, Jaddala and/or Gercus formations) in the core of the anticlines surrounded by younger Miocene and Pliocene rocks, which occupy the relatively low synclinal areas as well. Thus, the Quaternary sediments including the Pleistocene Tigris River terraces lie unconformably on these folded rocks. Lithologically, most of the exposed successions along the river channel are composed of carbonate and clastic rocks. 
The Recent sediments of Tigris River consist mainly of loose to fairly well- indurated deposits of sands, silts and mud. There are minor deposits of pebbles in some upstream areas and mostly of local origin, eroded from the adjacent sedimentary formations (Al-Juboury et al., 2001d).

\section{METHODS AND MATERIALS}

Twenty samples of recent sandy sediments were chosen for heavy mineral analysis from the nine localities shown in Figure (1) and Table (1). Heavy minerals from the 0.25 $0.063 \mathrm{~mm}$ size fraction were separated in order to avoid the worst effects of the varying density, shape and size of different heavy minerals due to hydraulic differentiation (Hubert, 1971). Concentrations of heavy minerals were carried out by means of high density liquid, bromoform, $\mathrm{CHBr}_{3}$ (Sp.Gr., 2.85). Heavy minerals were identified using standard petrographic procedures.

Morphology of the studied kyanite and staurolite was examined by scanning electron microscopy. Scanning electron microscopic analysis was performed using Cam Scan MV 2300 at the Institute of Paleontology, Bonn University, Germany with a calibrated energy dispersive X-ray analysis system. Chemical analyses of these minerals were carried out at Bonn University, Germany; A CAMEBAX electron-probe microanalyzer was used. Representative chemical analysis of these minerals is shown in Table ( $\boldsymbol{Y})$.

\section{MINERALOGY}

Heavy mineral suite of the recent sediments taken from the Tigris River and its tributaries from northern Iraq is composed mainly of opaque minerals which include magnetite, chromite and/or chromian spinels, hematite, ilmenite, goethite and pyrite and non-opaque minerals which include epidotes, pyroxenes, amphiboles, garnet, zircon, tourmaline, rutile, kyanite, staurolite, olivine, sphene, apatite, in addition to white mica, biotite, and chlorite Table (1).

Kyanite is observed in gray to green in color, with good cleavage and elongated bladed forms. Staurolite is represented by a brownish to golden yellow variety which shows pleochroism in golden yellow (Fig. 2). Sometimes, a pronounced conchoidal fracture with numerous sinuous lines of minute opaque inclusions are observed which are believed to be carbonaceous materials (Hutton, 1950).

Scanning electron micrographs clearly show the habit and the common processes affecting on the surface texture of the studied minerals. Chemical etching in the form of grooves and several types of pits is observed (Fig.3).

Kyanite with broken edges and some dissolution pits (Fig. 3A-B) and different dissolution signs of lines, grooves, pit and v-shapes (Fig. 3C-D) on staurolite are commonly observed. This study of surface textures has revealed the combined affects of mechanical attrition and chemical etching during the transport of these mineral grains by the river water and possible effects prior to transportation in the river. Many of these features may attributed to difference in $\mathrm{pH}$ of the water (as a result of evaporation) between summer and winter and even between day and night affect sediments in river system. 
Mohsin M. Ghazal and Ali I. Al-Juboury 

Table (1) Average relative percentage of the heavy minerals in the studied Tigris River sediments. See Figure (1) for sample locations. Samples with stars are the analyzed samples for chemical analysis of detrital kyanite and staurolites.

\begin{tabular}{|c|c|c|c|c|c|c|c|c|c|c|c|c|c|}
\hline Opaque & Amphiboles & Pyroxenes & Epidotes & Garnet & $\begin{array}{l}\text { Flak } \\
\text { Mus }\end{array}$ & $\begin{array}{l}y \text { min } \\
\text { Bio. }\end{array}$ & $\begin{array}{c}\text { erals } \\
\text { Chl. }\end{array}$ & Zircon & Tourm. & Rutile & Kyanite & Staurolite & Spinel \\
\hline 38.3 & 3.9 & 6.2 & 18.4 & 3.5 & 11.2 & 5.3 & 10.1 & 1.0 & 1.2 & 0.1 & 1.2 & 0.1 & 0.1 \\
\hline 35.5 & 4.4 & 5.8 & 18.1 & 5.7 & 13.1 & 5.8 & 9.8 & 0.5 & 0.7 & -- & 0.5 & 0.2 & -- \\
\hline 33.7 & 2.3 & 2.6 & 12.7 & 2.4 & 18.0 & 10.5 & 15.8 & 0.3 & 0.4 & -- & 0.4 & -- & -- \\
\hline 47.1 & 2.9 & 4.8 & 19.2 & 14.2 & 6.4 & 1.7 & 3.2 & 0.3 & 0.6 & 0.1 & -- & 0.2 & 0.2 \\
\hline 54.1 & 2.7 & 7.4 & 22.1 & 2.2 & 5.4 & 0.7 & 3.0 & 0.5 & 0.9 & -- & 0.3 & -- & -- \\
\hline 52.3 & 3.0 & 7.6 & 24.2 & 3.9 & 5.1 & 0.4 & 1.9 & 0.3 & 0.8 & -- & 0.4 & -- & -- \\
\hline 52.1 & 2.8 & 6.8 & 25.1 & 6.8 & 3.4 & 1.1 & 0.3 & 0.6 & 0.9 & 0.5 & 0.7 & 0.4 & -- \\
\hline
\end{tabular}




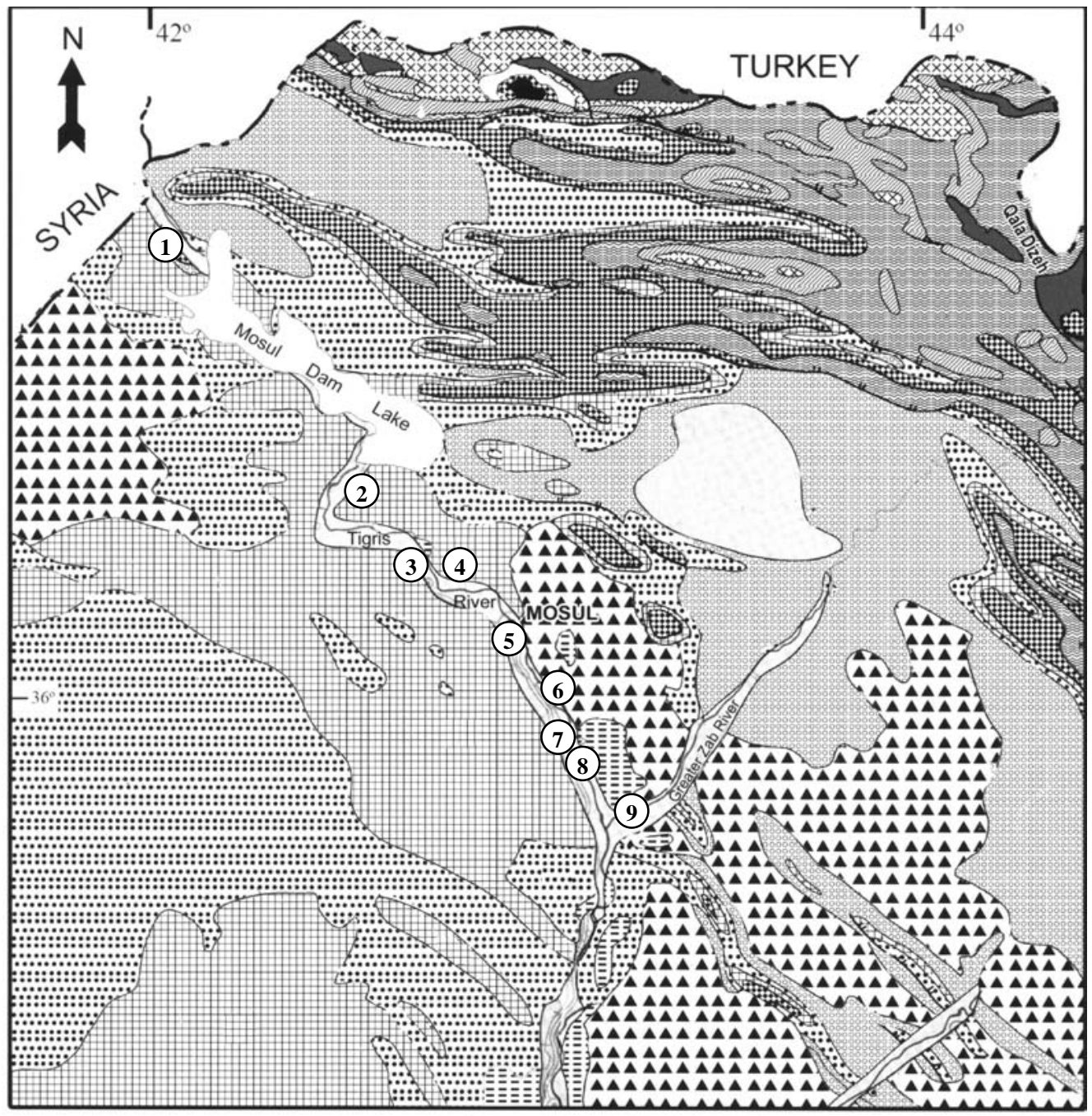

$\square$ Holocene flood plain deposits

Pleis-Hol. polygenetic synclinal filling

既 Pleistocene river terraces

Pliocene Mukdadiyah \& Bai Hassan formations (Bakhtiari group)

․․․․: Miocene Injana (Ćpper Fars) Formation

M. Miocene Fat'ha (Lower Fars, Formation

L. Niocene (Serkagni, Euphrates, Dhiban \& Jeribe) formations Paleocene (Pilaspi, Avanah \& Jaddala) formations Eocene (Gercus, Aaliji, Khurmala \& Kolosh) formations

Cret. (Shiranish, Aqra, Qamchuqa \& Garagu) formations

Jur. (Chia Gara, Naokelekan \& Saraglu) formations

XX人 Tri. (Baluti, Kurra China \& Geli Khana) formations

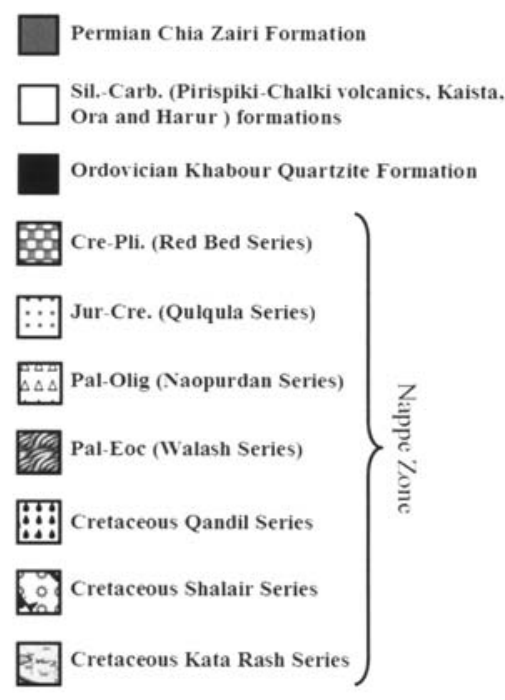

Fig.1: Geological map of northern Iraq showing the geologic formations of the Ordovician to Recent, and sample locations (modified from the Geological map of Iraq, 1986). See Table (1) for more information about sample locations. 


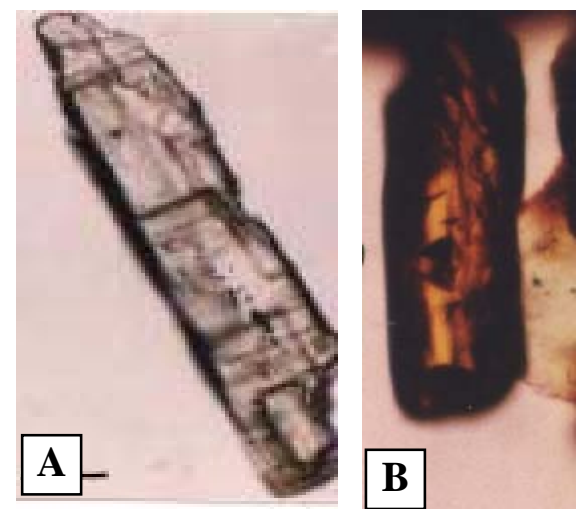

Fig. 2: Photomicrographs of the studied kyanite and staurolite. A: Kyanite bladed grain with observed cleavage. B: Elongated staurolite grain showing golden yellow color with carbonaceous materials. (Ordinary light, 20X).
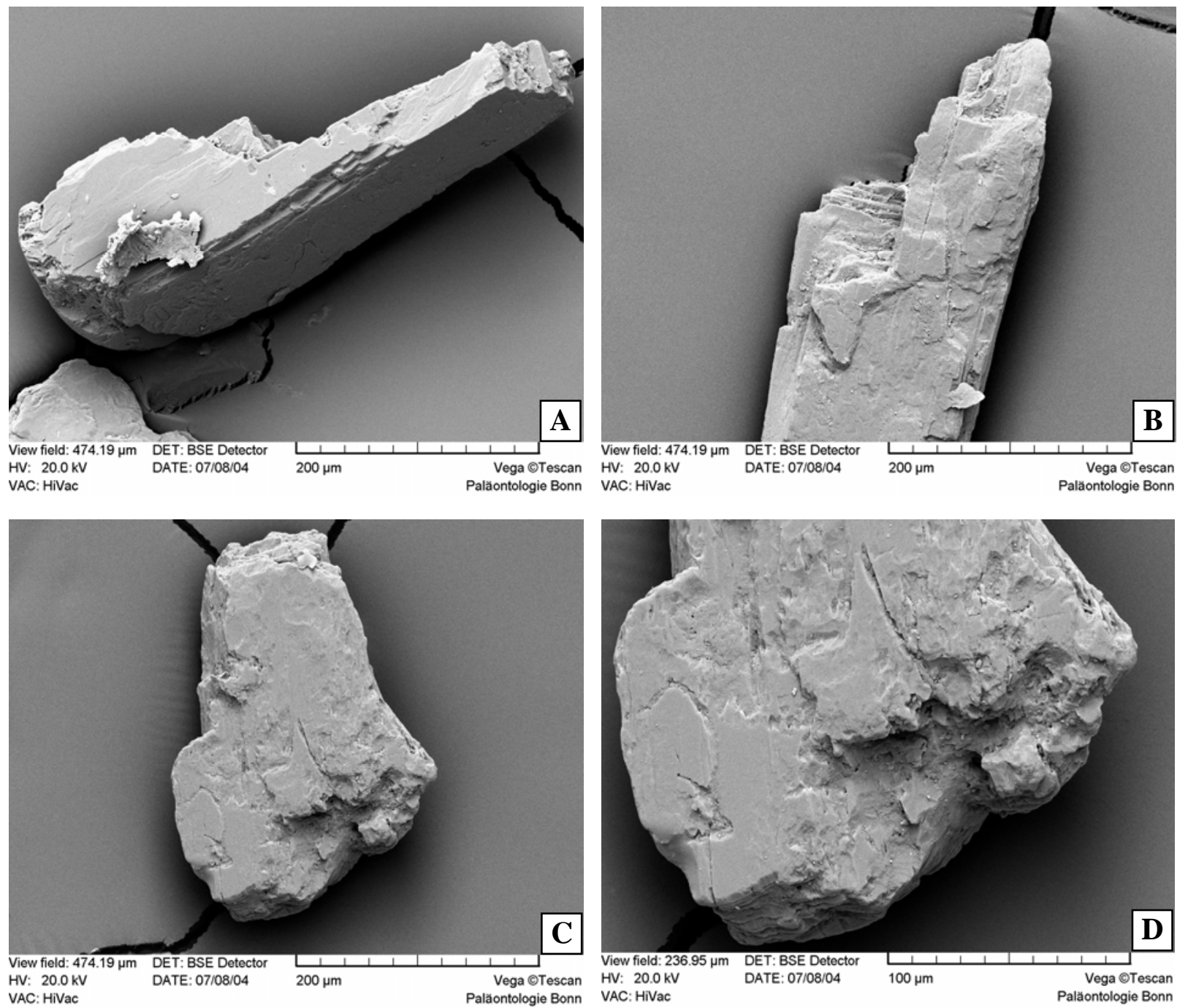

Fig. 3: Scanning electron microscopic images which illustrate, A: A kyanite grain with bladed form, broken edges and some dissolution pits. B: Enlarged view of A, showing the dissolution on the cleavage surfaces. C: A staurolite grain with anhedral shape and common dissolution lines. D: Enlarged view of C, illustrates different dissolution signs of lines, grooves, pit and v-shapes. 


\section{CHEMISTRY}

Kynanite is a triclinic polymorph of the aluminosilicates having the chemical formula $\mathrm{Al}_{2} \mathrm{SiO}_{5}$. It is commonly found in medium- to high-grade metamorphic regional rocks, such as pelitic schists. Kyanite is diagnostic of areas subjected to minimum pressure of about 3 Kbars (Hurlbut and Klein, 1977), which is known as kyanite staibility field in the phase diagram of andalusite-kyanite-sillimanite. Moreover, kyanite is often associated with garnet, staurolite and corundum (Hurlbut and Klein, 1977).

The chemical analysis of the present work reveals that the detrital kyanite is composed mainly of about $64 \% \mathrm{Al}_{2} \mathrm{O}_{3}$ and about $36 \% \mathrm{SiO}_{2}$, while other constituents are nearly negligible $(<<1 \%)$ (Table $r$ ). When compared with the kyanite analyses of $\mathrm{Al}_{2} \mathrm{SiO}_{5}$-bearing muscovite quartzite of central and western Turkey (Whitney, 2002), there is a good similarity $\left(37 \% \mathrm{SiO}_{2}\right.$ and $\left.63 \% \mathrm{Al}_{2} \mathrm{O}_{3}\right)($ Table $r)$. The value of $\mathrm{Fe} /(\mathrm{Fe}+\mathrm{Mg})$ is $0.833-0.922$ for the kyanite of the present study, and 1.000 for the kyanites of Turkey due to the absence of $\mathrm{Mg}$ cations in their structure.

The structure of staurolite resembles closely that of kyanite with layers of $4 \mathrm{Al}_{2} \mathrm{SiO}_{5}$ $\left(\mathrm{AlO}_{6}\right.$ octahedra in chain parallel to c-axis with layers of $\mathrm{Fe}_{2} \mathrm{AlO}_{3}(\mathrm{OH})$ composition), (Hurlbut and Klein, 1977). Staurolite is formed during regional metamorphism of Al-rich rocks in schists and gneisses. It is often associated with almandite garnet and kyanite in medium-grade metamorphic rocks, and it may grow on kyanite in parallel orientation. It is commonly used as an index mineral of medium-grade metamorphism (Hurlbut and Klein, 1977).

The analyzed detrital staurolite of the present work is composed essentially of $\mathrm{Al}_{2} \mathrm{O}_{3}$ (about $55 \%$ ), $\mathrm{SiO}_{2}$ (about $28 \%$ ), $\mathrm{FeO}$ (about $13 \%$ ), $\mathrm{MgO}$ (about $2 \%$ ). Other constituents are mostly absent (Table $r$ ). The staurolite in schist and gneiss of Turkey as given by Whitney (2002) is composed of $\mathrm{Al}_{2} \mathrm{O}_{3}$ (about $55 \%$ ), $\mathrm{SiO}_{2}$ (about 28\%), $\mathrm{FeO}$ (12-13\%), $\mathrm{MgO}(1-2 \%)$ and less than $1 \%$ of each of other constituents (Table $\mathrm{r}$ ). 
Table r: Chemical composition ( $\mathrm{wt} \%$ ) of kyanite and staurolite of the present study and Turkey.

\begin{tabular}{|c|c|c|c|c|c|c|c|c|}
\hline & \multicolumn{4}{|c|}{ Kyanite } & \multicolumn{4}{|c|}{ Staurolite } \\
\hline & $\mathbf{K}_{1}$ & $\mathbf{K}_{2}$ & $\begin{array}{c}\mathrm{KY}_{1} \\
(\mathrm{n}=19)\end{array}$ & $\begin{array}{c}\mathbf{K Y} \mathbf{Y}_{2} \\
(\mathrm{n}=5)\end{array}$ & $\mathrm{S}_{1}$ & $\mathrm{~S}_{2}$ & $\begin{array}{c}\mathrm{ST}_{1} \\
(\mathrm{n}=5)\end{array}$ & $\begin{array}{c}\mathrm{ST}_{2} \\
(\mathrm{n}=36)\end{array}$ \\
\hline $\mathrm{SiO}_{2}$ & 36.23 & 36.69 & 36.79 & 37.04 & 28.44 & 28.36 & 27.39 & 27.72 \\
\hline $\mathrm{Al}_{2} \mathrm{O}_{3}$ & 64.58 & 64.62 & 63.06 & 62.87 & 55.00 & 54.82 & 55.46 & 54.13 \\
\hline $\mathrm{TiO}_{2}$ & 0.00 & 0.00 & 0.03 & 0.00 & 0.00 & 0.00 & 0.30 & 0.66 \\
\hline $\mathrm{Cr}_{2} \mathrm{O}_{3}$ & 0.07 & 0.05 & 0.00 & 0.00 & 0.06 & 0.01 & 0.00 & 0.00 \\
\hline $\mathrm{FeO}$ & 0.22 & 0.21 & & & 13.02 & 13.11 & 11.97 & 12.82 \\
\hline $\mathrm{Fe}_{2} \mathrm{O}_{3}$ & & & 0.80 & 0.63 & & & & \\
\hline $\mathrm{MnO}$ & 0.00 & 0.00 & 0.02 & 0.00 & 0.10 & 0.20 & 0.36 & 0.48 \\
\hline $\mathrm{MgO}$ & 0.02 & 0.01 & 0.02 & 0.03 & 2.12 & 1.99 & 0.98 & 1.96 \\
\hline $\mathrm{CaO}$ & 0.00 & 0.00 & 0.00 & 0.00 & 0.00 & 0.00 & 0.00 & 0.06 \\
\hline $\mathrm{Na}_{2} \mathrm{O}$ & 0.01 & 0.02 & 0.00 & 0.00 & 0.00 & 0.00 & 0.00 & 0.16 \\
\hline $\mathrm{K}_{2} \mathrm{O}$ & 0.01 & 0.00 & 0.00 & 0.00 & 0.00 & 0.00 & 0.00 & 0.03 \\
\hline $\mathrm{ZnO}$ & & & & & & & 1.49 & 0.59 \\
\hline Total & 101.14 & 101.60 & 100.72 & 100.57 & 98.74 & 98.49 & 97.94 & 98.61 \\
\hline \multirow[t]{2}{*}{$\mathrm{Fe} /(\mathrm{Fe}+\mathrm{Mg})$} & 0.833 & 0.922 & 1.000 & 1.000 & 0.775 & 0.787 & 0.872 & 0.785 \\
\hline & \multicolumn{4}{|c|}{ Cations per cent on the basis of $5 \mathrm{O}$} & \multicolumn{4}{|c|}{ Cations per cent on the basis of $46 \mathrm{O}$} \\
\hline $\mathrm{Si}$ & 0.97 & 0.98 & 0.98 & 1.00 & 7.77 & 7.78 & 7.64 & 7.64 \\
\hline $\mathrm{Al}$ & 2.04 & 2.03 & 2.00 & 1.99 & 17.71 & 17.72 & 18.22 & 17.59 \\
\hline $\mathrm{Ti}$ & 0.00 & 0.00 & 0.00 & 0.00 & 0.00 & 0.00 & 0.06 & 0.14 \\
\hline $\mathrm{Cr}$ & 0.001 & 0.001 & 0.00 & 0.00 & 0.01 & 0.00 & 0.00 & 0.00 \\
\hline $\mathrm{Fe}$ & 0.005 & 0.005 & 0.02 & 0.01 & 2.98 & 3.01 & 2.79 & 2.96 \\
\hline $\mathrm{Mn}$ & 0.00 & 0.00 & 0.00 & 0.00 & 0.02 & 0.05 & 0.08 & 0.11 \\
\hline $\mathrm{Mg}$ & 0.001 & 0.0004 & 0.00 & 0.00 & 0.86 & 0.81 & 0.41 & 0.81 \\
\hline $\mathrm{Ca}$ & 0.00 & 0.00 & 0.00 & 0.00 & 0.00 & 0.00 & 0.00 & 0.02 \\
\hline $\mathrm{Na}$ & 0.001 & 0.001 & 0.00 & 0.00 & 0.00 & 0.00 & 0.00 & 0.08 \\
\hline $\mathrm{K}$ & 0.00 & 0.00 & 0.00 & 0.00 & 0.00 & 0.00 & 0.00 & 0.01 \\
\hline
\end{tabular}

$\mathrm{K}_{1}, \mathrm{~K}_{2}, \mathrm{~S}_{1}$ and $\mathrm{S}_{2}$ : Kyanite and staurolite of the present study (Wana and Makhlat).

$\mathrm{KY}_{1}$ and $\mathrm{KY}_{2}$ : Kyanite in quartzite of Turkey (data from Whitney, 2002).

$\mathrm{ST}_{1}$ and $\mathrm{ST}_{2}$ : Staurolite analyses in schist and quartzite of Turkey respectively (data from Whitney, 2002).

\section{DISCUSSION AND CONCLUSIONS}

Mineralogical description of the studied kyanite and staurolite from the recent sediments of the Tigris River from northern Iraq has revealed that these minerals are present in varying quantities which indicate the metamorphic contribution on the source of the heavy minerals suite.

Heavy minerals suite suggests their derivation from a complex metamorphic and igneous terrain. Based on the mineralogical and chemical indicators, the probable provenance of the heavy minerals, in general, includes mafic and ultramafic igneous rocks, metamorphic rocks, and the ophiolitic complexes of northeastern Iraq and south Turkey.

The metamorphic origin of Tigris River sediments is evidenced by the presence of epidotes, garnet and amphiboles which form together an average relative frequency of 
more than $25 \%$ in some of the studied localities (Table 1). These minerals probably come from the erosion of metavolcanic rocks associating the Walash and ophiolite complexes, whereas, kyanite and staurolite come from other sources such as the metapelitic rocks of nappes probably in Iran.

The kyanite and staurolite are genetically formed in medium- to high-grade metamorphic rocks. This is described by Whitney (2002) in his research about the metamorphic suite in the central and western parts of Turkey. Moreover, a geochemical comparison has been accomplished between analysis of both kyanite and staurolite found in schists and quartzites in Turkey and the detrital kyanite and staurolite of the recent fluviatile sediments of northern Iraq, where the latter ones are thought to be the products of the disintegration process of the former metamorphic rocks in Turkey, whereas the comparison reveals a great resemblance between them. Other studies like that of Fornelli and Picaretta (1997) and Acquafredda et al. (1997) have realized the concept of the similarity between the detrial grains and their equivalents in the expected provenance.

The chemical composition and the occurrence of detrital kyanite and staurolite constrain the source rocks of them, where they resemble the schist and quartzite metamorphic rocks of Turkey.

\section{REFERENCES}

Acquafredda, P., Fornelli, A., Piccarreta, G. and Summa, V., 1997. Provenance and Tectonic Implication of Heavy Minerals in Pliocene-Pleistocene Siliciclastic Sediments of the Southern Apennines, Italy. Sed. Geol., Vol.113, pp.149-159.

Al-Juboury, A.I., 1994. Petrology and Provenance of the Upper Fars Formation (Upper Miocene), Northern Iraq, Acta Geologica Universitatis Comenianae Bratislava Vol. 50, pp.45-53.

Al-Juboury, A.I., 2001. Paleogeography and Provenance of Injana Formation, Iraq: Based on Petrography and Heavy Minerals Distribution. Iraqi Jour. Earth Sci., Vol.1, pp.36-51.

Al-Juboury, A.I., Al-Miamary, F.A. and Ghazal, M.M., 2001a. Heavy Minerals Distribution of the Recent Sandy Deposits of Tigris River and its Tributaries, North Iraq. Raf. Jour. Sci., Vol.12, pp.145-161.

Al-Juboury, A.I., Al-Naqib, S.Q. and Al-Juboury, A.M., 2001b. Sedimentology and Mineralogy of the Upper Clastic Units of Fat'ha Formation, South of Mosul, Iraq. Dirasat (Pure Sciences) Jordan, Vol. 28, pp.80-106.

Al-Juboury, A.I., Ghazal, M.M. and Al-Naqib, S.Q., 2001c. Development and Heavy Minerals of the Tigris River Terraces, North Iraq. Dirasat (Pure Sciences) Jordan Vol. 28: pp.245-259

Al-Juboury, A.I., Al-Miamary, F.A. and Ghazal, M.M., 2001d. Size Analysis and of the Sandy Sediments of Tigris River and its Tributaries, North Iraq. Iraqi Journal of Earth Sciences, Vol. 1, pp.72-90.

Al-Rawi, Y., 1980. Petrology and Pedimentology of the Gercus Red Beds Formation (Eocene), Northeastern Iraq. Iraqi Journal of Science, Vol. 21, pp.132-188.

Buday, T., 1980. The Regional of Iraq. Stratigraphy and Palaeogeography. State Organization for Minerals, Baghdad, Iraq, 445p. 
Dunnington, H.V., 1958. Generation, Migration, Accumulation and Dissipation of Oil in Northern Iraq. in (Habitat of Oil), L.G. Weeks, ed. Am Assoc Petrol Geologists, A Symposium: pp.1194-1251.

Fornelli, A. and Piccarreta, G., 1997. Mineral and Chemical Provenance Indicators in Some Early Miocene Sandstones of the Southern Apennines (Italy). Eur. J. Mineral., Vol.9, pp.433-447.

Geological Map of Iraq, 1986. Series Scale 1:1 000 000. Directorate General of Geological Survey and Mineral Investigation, Baghdad, Iraq.

Hubert, J.F., 1971. Analysis of Heavy Mineral Assemblages. Procedures in Sedimentary Petrology. In: Carver, P.E. (ed), pp.453-478, Wiley.

Hurlbut, C.S.JR. and Klein, C., 1977. Dana's Manual of Mineralogy. 19th ed., John Willey and Sons, New York, 532p.

Hutton, C.O., 1950. Studies on Heavy Detrital Minerals. Bull. Geol. Soc. America, Vol.61, pp.635-710.

Jawad Ali, A., 1977. Heavy Minerals Provinces of the Recent Sediments of EuphratesTigris Basin. Jour. Geol. Soc. Iraq, Vol.10, pp.33-48.

Morton, A.C., 1985. Heavy Minerals in Provenance Studies. Provenance of Arenites (Zuffa, G.G., ed.), pp.249-277, NATO ASI Series C 148.

Morton, A.C. and Johnsson, M.J., 1993. Factors Influencing the Composition of Detrital Heavy Mineral Suites in Holocene Sands of the Apure River Drainage Basin, Venezuela. Geol. Soc. America. Special paper, Vol.284, pp.171-185.

Phillip, G., 1968. Mineralogy of Recent Sediments of Tigris and Euphrates Rivers and Some of the Older Detrital Deposits. Jour. Sed. Petrol., Vol.38, pp.35-44.

Whitney, D.L., 2002. Coexisting Andalusite, Kyanite, and Silliminite: Sequential Formation of three $\mathrm{Al}_{2} \mathrm{SiO}_{5}$ Polymorphs During Progressive Metamorphism Near the Triple Point, Sivrihisar, Turkey. American Mineralogist, Vol. 87, pp.405-416. 